\title{
1 Food Insecurity in the United States of America: A Comparison 2 between the Great Recession and the COVID-19 Pandemic
}

3

4 Anne Mook, Ph.D. \& Emily Swanson, MLA

5

6

7

INTRODUCTION a rapid increase in food insecurity.

The Severe Acute Respiratory Syndrome Coronavirus 2 (SARS-CoV-2), also known as COVID-19, altered everyday life in the United States of America and around the world. In 2020, $20,727,942$ people residing in the United States of America were infected, with 356,666 succumbing to the virus." I(Center for Disease Control 2021). Social distancing measures discouraged in-person interaction which led to many businesses, schools, and food services having to operate at reduced capacity or to close completely (Ryan 2021). Soon after, revenues declined, employees were dismissed, and numerous businesses were forced to file bankruptcy (Pak et al. 2020). Consequently, the number of people in the United States of America who struggle to put food on the table has increased. Newspaper and media outlets showed long lines of people seeking assistance from food banks across the USA (Leddy et al. 2020). In summation, the economic ramification of spread mitigations strategies caused a severe economic crisis and

The pandemic is not the first economic crisis to bring about food insecurity in the United States of America. The Great Recession (December 2007 to June 2009) caused by the collapse of the U.S. housing bubble, also left a substantial number of residents of the USA unemployed and food insecure (Gundersen \& Ziliak 2018). To save the USA economy, the federal government 
24 approved unprecedented fiscal, monetary, and regulatory policies (Christiano et al. 2015).

25 Experts credit these policies for the economic recovery and argue generous government 26 intervention prevented a worse outcome (i.e., Blinder \& Zandi 2010; Lui et al. 2013). While

27 significant amounts of recovery aid were given to (financial) corporations which recouped rather quickly, much of the negative effects brought on by the Great Recession such as unemployment, rising food prices, and food insecurity were felt years beyond its official end date of June 2009

30 (Grusky, Western, \& Wimmer 2008; Redbird \& Grusky 2016). This chapter compares food

31 insecurity rates among adults and children during the Great Recession and the COVID-19

32 pandemic. We analyze the causes and mitigation strategies to prevent rising food insecurity rates

33 brought on by economic crises, lastly, we offer short-term and long-term recommendations to 34 prevent and reduce food insecurity in the future.

35 FOOD INSECURITY IN AMERICA

The lack of access to adequate nutrition is a persistent problem in the United States of

37 America, with significant spikes during the Great Recession and the COVID-19 pandemic (Myers

38 \& Painter, 2017). Feeding America - a network of more than 200 food banks across the USA defines food security as, "having access, at all times, to enough food for an active, healthy life for all household members (Feeding America 2014)." Research by Feeding America shows that

41 during the peak of food insecurity in 2010, caused by the Great Recession, $15.7 \%$ of adults did

42 not meet the criteria of being food secure (Gundersen et al. 2012). When the economy 43 recovered, food insecurity rates dropped slowly for adults to $15.2 \%$ in $2012,15.2 \%$ in $2014,13 \%$ 44 in 2016 , and $12.17 \%$ in 2018 , demonstrating that recovery to pre-Great-Recession food-security 
45 rates took nearly a decade (Gundersen et al. 2012). The food-insecurity rates for children, whose

46 development is more severely threatened by the lack of healthful nutrition, are much higher and

47 rise faster in times of economic downturn with $23.4 \%$ at its peak as an outcome from the Great

48 Recession in 2010, 22.7\% in 2012, 22.5\% in 2014, 18.1\% in 2016, and $16.9 \%$ in 2018 (Gundersen

49 et al. 2012) (see Table 1). Estimates for October 2020 from Feeding America already project a

50 more significant rise in food insecurity due to COVID-19 than during the Great Recession with a

51 food insecurity rate of $15.99 \%$ for adults and $24.27 \%$ for children. These estimates for October

522020 are based on alternative models as contemporary data is not yet available, and thereby

53 have greater margins of error (Gundersen et al. 2020). Given the higher-than-expected infection

54 rates and deaths in the Fall of 2020, the Winter of 2020/2021, and new lockdowns in various

55 states and cities, the food insecurity rates are likely to be underestimated in these latest models

56 (USDA 2021). Food insecurity is a salient problem in the USA, as the lack of sufficient and healthful

57 nutrition can lead to a variety of serious long-term negative outcomes, especially in children,

58 including declining mental health (Elgar et al. 2020), reduced academic performance (Lee et al.

59 2018), and poor physical health (Cook et al. 2006). Furthermore, studies show food-insecure

60 families are particularly vulnerable to pandemics as they are more prone to infection and

61 succumbing to the virus (Wolfson \& Leung 2020). Therefore, food insecurity is a critical social

62 justice issue which requires an immediate and long-term priority on the USA policy agenda.

63 - Table 1 here

64 FOOD PRICES AND AVAILABILITY 
The academic literature demonstrates that protectionist policies by key exporting

countries, panic-buying and increased demand in importing countries, and risks and uncertainties on the global market led to rising food prices during and after the Great Recession (Aday \& Aday 2020; Gundersen \& Ziliak 2018; US Department of State 2011; Perz et al. 2018). In particular, the prices of nutritionally valuable foods such as fruits, vegetables, and eggs increased significantly during the Great Recession (Mead et al. 2020). Early in the COVID-19 pandemic outbreak, people of the USA feared supply challenges and started hoarding food, disinfectants, and toilet paper (Garbe, Rau, \& Toppe 2020). This response is not entirely unwarranted because COVID-19 restricted the movement of workers, caused changes in consumer demand, forced certain production facilities to temporarily close, increased the restriction of food trade policies, and created financial challenges in the food supply chain (Aday \& Aday 2020). Early in the pandemic, the United States experienced an oversupply of meats, fish, and dairy due to limited demand from the hospitality and tourism industry. However, many links in the supply chain, such as producers, wholesalers, and retailers, have managed to reinvent themselves by quickly redirecting from restaurants and institutional customers to retail markets (Nicola et al. 2020; US Bureau of Labor Statistics, 2020). This shift was partly possible because of effective collaboration with the United States Food and Drug Administration (FDA), which offered flexibility. For example, the FDA extended delivery hours to replenish supermarkets, in addition to lifting some of the packaging and labeling requirements for certain foods to redirect the oversupply caused by reduced away-from-home meals and increased retail demand (FDA 2020; Mazili 2020; Reiley 2020; Nicola et al. 2020). As a result of a swift reorganization in the U.S. agri-food system, concurrent with the plummeting oil values which comprise a substantial portion of the cost of 
87 food production, food prices remained relatively stable (US Bureau of Labor Statistics 2020). In other words, while rising food prices can be partially to blame for food insecurity during the Great Recession, the COVID-19 pandemic of 2020 did not have the same effect. To illustrate, the data from the Bureau of Labor Statistics (2020) showed food prices increased in June 2008 on average

91 by about $15 \%$ compared to June 2007, while the price difference between June 2020 and June

922019 was less than 3\% (for price increases for specific products, see Table 1).

93 - Table 2 here

94

\section{UNEMPLOYMENT RATES BY GENDER AND RACE}

Now that we have established food availability and affordability has remained relatively stable compared to pre-COVID-19 levels, we evaluate another major crisis, rising levels of unemployment (Kochhar 2020). Both the Great Recession and the health crisis of COVID-19 had immense economic impact resulting in mass unemployment. We find the unemployment rate for workers active in the labor market was significantly higher in May 2020 at $13 \%$ than at the unemployment peak of the Great Recession in 2020 at 10\% (Bureau of Labor Statistics 2020). With voluntary and mandatory lockdowns, the dynamics of unemployment are dissimilar to the Great Recession, with many blue-collar workers being dismissed while communications technology allowed many white-collar workers to work remotely (Akkermans, Richardson \& Kraimer 2020). One of the most notable hard-hit demographic group is women, with an unemployment rate of $14.3 \%$. at the height in May 2020, compared to men with an unemployment rate of $11.9 \%$. The demographic statistics are drastically different compared to the height of the Great Recession in July 2010 when the unemployment rate was $9.4 \%$ and $12.3 \%$ 
108 for women and men respectively (Bateman \& Ross 2020). Moreover, minorities have been more 109 affected than Whites as we see a $16.7 \%$ unemployment rate for Asian women, $17.2 \%$ for black 110 women, and $19.5 \%$ for Hispanic women, compared to an $11.9 \%$ unemployment rate for White 111 women (Bureau of Labor Statistics 2020). Immigrant workers were also substantially impacted, 112 especially unauthorized ones, who are more vulnerable to job loss during economic crises. 113 Education is a protective factor against economic downfall with an unemployment rate for 114 bachelor holders at 7.2\% in May 2020 vs 5.3\% at the Great Recession peak, the workforce with 115 some college education had an unemployment rate of $12.9 \%$ vs $9.0 \%$, high school graduates 116 suffered an unemployment rate of $15 \%$ vs $11.9 \%$, and those without a high school diploma were 117 most likely to be unemployed at $18.5 \%$ in May 2020 vs $17.9 \%$ during the Great Recession (for 118 unemployment statistics by demographics see Table 2). Women constitute most employees in education and hospitality, some of the hardest-hit sectors during COVID-19, which explains at least in part why women are experiencing more job 121 impact (Kochhar 2020). Millions of women, particularly single parents, were already struggling to 122 support not only themselves but also their families on low wages before the lockdowns (Blau \& 123 Kahn 2017; Lu et al. 2020). The challenges women face in the labor market are not new as for 124 decades low wages have long been associated with female-dominated occupations (Power 125 2020). Therefore, it is unsurprising that the COVID-19 pandemic has forced millions of women 126 and their families into greater financial difficulties. Analysts at Brookings observed based on the 1272018 American Community Survey data, that $46 \%$ of women worked in low paying jobs, with 128 median earnings of $\$ 10.93$ per hour before COVID-19 (Bateman \& Ross 2020). Black (54\%) and 129 Hispanic women (64\%) are more likely to be in low-earning jobs than White women (40\%). 
130 Fifteen percent of these low-earning women are single parents, $63 \%$ are in their prime working

131 years (ages 25-54), and 57\% are working full time, suggesting the work is not solely a side job.

$13241 \%$ percent of female workers live in households that earn less than $200 \%$ of the federal poverty

133 level (which is comparable to approximately $\$ 43,000$ for a family of three) (Ibidem). Many

134 women who were able to maintain their employment struggled too, because female-dominated

135 positions such as healthcare, education, hospitality, and cleaning have limited options for

136 telework. These women must physically go to work, thereby increasing the risk of contracting

137 COVID-19 and contaminating their families (Baker, Peckham \& Seixas 2020; Fisher et al. 2020).

138 Working mothers are further burdened with finding and paying for childcare since schools and

139 daycares are often operating at reduced hours or being closed entirely due to COVID-19

140 (Zammaro, Perez-Arce, \& Prados 2020). Therefore, women with young children need to find

141 alternative and affordable childcare arrangements that are not always available (Petts, Carlson,

142 \& Pepin 2020; Morrissey 2020). Ultimately, the COVID-19 pandemic particularly threatens the

143 livelihoods of low-income families, women, and minorities, groups already facing social 144 inequalities.

148 for families when jobs abruptly disappear. In 1935 the United States established a federal-state unemployment insurance program to temporarily help laid-off workers if they are actively looking for a new job (Wandner 2019). Although unemployment benefits vary state by state, 
151 most states provide up to 26 weeks of benefits to replace about half of a worker's last earned 152 wages with a capped maximum. In the past decade, unemployment insurance payments were 153 about $\$ 387$ per week nationwide, with the lowest average unemployment insurance benefits in 154 Mississippi at $\$ 215$ per week to the highest average unemployment insurance benefits of $\$ 550$ 155 per week in Massachusetts. Since payments are capped, unemployment insurance benefits 156 substitute a higher percentage of the last earned wages of lower-income workers than of higher157 income workers (Kovalski \& Sheiner 2020). Unfortunately, in a major crisis such as the Great 158 Recession, regular unemployment insurance benefits do not sufficiently help to keep affected 159 workers and their families afloat. Hence, during the Great Recession, Congress enacted the 160 Emergency Unemployment Compensation program, which temporarily extended the 161 unemployment insurance benefit duration from 26 weeks to 99 weeks (Hagedorn et al. 2013). 162 The Emergency Unemployment Compensation program only provided benefits to those eligible 163 for regular state unemployment insurance benefits. Additionally, in 2009, Congress signed the 164 American Recovery and Reinvestment Act which directed benefits to workers including a weekly 165 compensation increase of $\$ 25$ for all recipients of unemployment assistance programs and 166 "suspended income taxation of the first \$2,400 of unemployment benefits received for taxable 167 years beginning after December 31, 2008 (Congressional Research Service 2020: 8)." Research 168 shows government stimulus packages were critical, but not enough, in protecting the most 169 vulnerable and rebuilding the economy. Despite resistance the American Recovery Reinvestment 170 act was terminated on December 29, 2012 (National Employment Law Project 2012; Boteach, 171 2012). 
As the COVID-19 pandemic caused unprecedented job loss and changed life-work

173 dynamics across the United States, Congress approved the Families First Coronavirus Response

174 Act (FFCRA) in March 2020, which offered a one-time $\$ 1200$ stimulus payment for all adults

175 regardless of employment status and an additional \$500 per dependent (Edmondson 2020). The

176 FFCRA also increased unemployment insurance benefits by $\$ 600$ per week from March 2020 to

177 July 2020 to help families pay for necessities (Department of Labor 2020). While research shows

178 families on unemployment benefits were more likely to become food insecure (Raifman et al.

179 2021), Republicans and Democrats could not reach an agreement for an extension of the relief

180 package to distribute additional unemployment compensation. Republicans argued the

181 additional $\$ 600$ per week was too high, therefore workers would rather stay home and collect

182 unemployment benefits than go back to work. Democrats contended there was not sufficient

183 work available, moreover, the additional unemployment benefits would boost the economy

184 (Werner 2020). The Republican party made a counterproposal which offered 70 percent of the

185 last earned wages starting in October, in addition to a $\$ 200$ per week bonus until then. Democrats

186 rejected this proposal maintaining the assistance was not sufficient and would take too long for

187 states to set up a new unemployment insurance program. During these negotiations,

188 unemployed workers did not receive any much-needed compensation (Long 2020). Eventually,

189 in late December Congress approved a new relief package which pays an additional $\$ 300$ per

190 week between December 27, 2020, and March 13, 2021 (Terrell 2020). Typically, people who fall

191 in certain categories such as workers who leave their jobs voluntarily, students \& recent

192 graduates, self-employed \& freelancer workers, and undocumented \& immigrants will not qualify

193 for unemployment insurance benefits (Long \& Bhattarai 2020). However, to offer affected 
194 families in crisis additional assistance the FFCRA expanded eligibility to include part-time workers, 195 freelancers, independent contractors, and the self-employed (Department of Labor 2020). Yet, 196 undocumented migrant workers and those seeking their first jobs such as new high school and 197 college graduates are not covered by the temporary pandemic relief packages (Kru \& Brantley 198 2020; Haar 2021). In addition to job loss, many individuals were suddenly unable to go back to work because of childcare needs or fear of exposure to the virus and potential transmission to themselves 201 and/or vulnerable family members (Petts, Carlson \& Pepin 2020). Therefore, the FFCRA made the 202 requirements for availability to work more flexible. For instance, it waived the requirement to be 203 actively looking for work, eliminated one-week waiting periods, and workers can quit for certain 204 reasons which are deemed a 'good cause' such as to escape a domestic violence situation, taking 205 care of an immediate family member, or to accompany a spouse who is relocating for 206 employment (Department of Labor 2020). The Department of Labor also enacted new paid leave 207 regulations, which allows workers to take "up to two weeks of paid sick leave at the employee's 208 regular rate of pay where the employee is unable to work because the employee is quarantined, 209 and/or experiencing COVID-19 symptoms and seeking a medical diagnosis (Department of Labor 210 2020)." Workers can also request "up to twelve weeks of paid family and medical leave at two211 thirds the employee's regular rate of pay, where an employee, who has been employed for at 212 least 30 calendar days, is unable to work due to a bona fide need for leave to care for a child 213 whose school or childcare provider is closed or unavailable for reasons related to COVID-19 214 (Ibidem 2020)." 
In times of personal or national crises, individuals and their families rely on government

217 food assistance. To assist vulnerable families, the Food Stamp program was established in 1939

218 as a way to help unemployed citizens of the USA during the Great Depression (1928-1939) (USDA

219 2018; Wilde \& Nord 2005). During the Great Recession (2007-2009), the program was revamped

220 under the new name Supplemental Nutrition Assistance Program (SNAP) and 'stamps' or

221 'coupons' were replaced with Electronic Benefit Transfer (EBT) cards (Bleich et al 2020). The

222 American Recovery and Reinvestment Act of 2009 invested \$45.2 billion to increase monthly

223 benefits for an average of $\$ 133$ per individual, or a $13.6 \%$ increase for food-insecure recipients

224 (Nord \& Prell 2011). However, this recovery act expired in 2013, resulting in a benefit decrease

225 of $5 \%$ of the total SNAP budget or about $\$ 10$ per participant per month ${ }^{1}$ (Center of Budget and

226 Policy Priorities 2013). During the Great Recession not only were the benefits increased, but also

227 the number of individuals and their families filing for food assistance to get additional assistance

228 rose significantly (see Table 4). While the number of participants decreased after its peak in 2013,

229 due to rising and persistent social inequality, participation in SNAP never went back to levels as

230 low as prior to the Great Recession.(USDA 2020).

As a result of the COVID-19 pandemic applications for SNAP participation is increasing and

232 the United States government has made several adjustments to meet the rising demand. To

233 reduce levels of acute food insecurity resulting from the unforeseen ramifications of the

234 pandemic, the USDA allows states to increase benefits to the maximum for SNAP participants

\footnotetext{
${ }^{1}$ Specific benefits may vary depending on household size and state
} 
235 who previously did not qualify for the full amount. Furthermore, states may provide food 236 replacement for children who would otherwise have received free or reduced-price meals from 237 schools. Finally, to reduce the risk of infection, the USDA piloted an online purchasing program 238 and approved flexible regulations to help states to manage increased workloads to ensure low239 income individuals and their families can gain and maintain access to EBT cardsCenter of Budget 240 and Policy Priorities 2020). Six days after the 2021 Presidential inauguration, Biden used an 241 executive order to expand the SNAP benefit by $15 \%$ for all recipients, which should assist families 242 with rising food costs, especially because children are missing free or reduced-cost breakfasts 243 and lunches at school which proved an effective strategy against childhood food insecurity 244 (Bartfeld \& Ahn 2011; Nova \& Reinike 2021).

While SNAP is critical in reducing food insecurity, it does not completely solve the food 246 insecurity problem as many food insecure individuals and their families are ineligible for SNAP 247 participation. To be eligible for participation, individuals must have a net income under the 248 federal poverty line (income limits are higher in Hawaii and Alaska) which is $\$ 1,064$ net a month 249 for an individual and \$2,184 net a month for a family of four. Furthermore, households should 250 have $\$ 2,250$ in countable resources or less, with the exception of $\$ 3,500$ or less if at least one 251 member of the household is 60 years or older or disabled (USDA 2020). The home is not included 252 in the countable resources, however other possessions such as vehicles do count as a resource 253 for SNAP purposes (although some exceptions apply for example if the individual/family lives in 254 the vehicle or the vehicle is needed for income-generating purposes such as truck or taxi drivers). 255 Students and undocumented immigrants generally cannot apply for food assistance. Maximum 256 monthly allotments range from $\$ 234$ for an individual to $\$ 782$ for a family of four but vary from 
257 state to state (Ibidem). At times individuals may not qualify for SNAP participation or the benefits

258 are insufficient and consequently need to resort to other resources to meet their needs.

259 Table 4 here

FOOD BANKS AND THE FARMER TO FAMILIES FOOD BOX PROGRAM

Food banks are integral in supplementing the nutritional needs for food-insecure

262 individuals and their families as government subsidies such as unemployment insurance and

263 SNAP do not cover the need for some social groups or are insufficient. In such cases, individuals

264 can resort to charitable organizations such as food banks to meet their nutritional needs.

265 Reliance on food banks has increased tremendously over time and spiked during economic crisis.

266 Using data from the 2002-2019 December Current Population Survey, Zeliak (2020) showed that

267 the receipt of charitable food among adults ages 18 and older increased over $70 \%$ from $5.7 \%$ in

2682002 to $9.8 \%$ in 2015 . While reliance on food banks declined slightly to $9.1 \%$ in 2019 , the COVID-

26919 pandemic created an unprecedented demand with $14.5 \%$ in June 2020 of the sample

270 indicating having received charitable food that month. Feeding America's research showed a 55\%

271 increase in demand for food assistance in the January to March 2021 compared to the year

272 before (Feeding America 2021). With COVID-19 still ravaging throughout the USA as of the time

273 of writing, the numbers above show that the reliance on food banks is substantially larger than

274 during the Great Recession. In addition to increased demand, since the pandemic began food

275 banks have been increasingly under pressure to mitigate food insecurity because of decreased

276 food donations and fewer available volunteers (Feeding America 2014). Even with a potentially

277 successful vaccination campaign underway, the economic setback for individuals and their 
278 families across the United States should not be underestimated as the effects are likely to be 279 protracted.

One measure to mitigate the reduced capacity of food banks and to assist producers unable to sell their goods to restaurants, hotels, and other foodservice businesses is the Farmers

282 to Families Food Box Program (Broad Leib et al. 2021). The FFCRA authorized the USDA to 283 purchase produce, meat, and dairy from companies, whose sales have been directly affected by 284 altered patterns of consumption due to the COVID-19 pandemic and to distribute this food 285 through food banks, community and faith-based organizations, and other non-profits to people 286 of the USA in need. The program delivered 132.8 million food boxes in 2020. As of January 2021, 287 this program has been renewed six times since May 15, 2020, and is currently expected to run 288 until April 2021 (USDA 2021).

\section{DISCUSSION}

This chapter shows the United States ought to anticipate long-term food insecurity which

291 despite mitigating measures such as unemployment insurance, increase in SNAP benefits, and 292 the Farmers to Families Food Box Program, is likely to be worse than the Great Recession. We 293 illustrated that notwithstanding the increase of government benefits, the Great Recession caused 294 a decade-long food insecurity crisis for many individuals, in particular children. Contrary to the 295 Great Recession, which particularly affected male-dominated fields such as construction workers, 296 the COVID-19 pandemic has particularly affected female-dominated professions such as those in 297 the leisure and education sectors. Furthermore, with schools operating at reduced capacity or 298 entirely online, many women are forced to (temporarily) leave their jobs as school and childcare 
options are unavailable or unaffordable. Therefore families, in particular female-headed and minority households with children, have faced significant financial challenges and will struggle to feed their families adequately. While additional unemployment benefits, work leave options, expansion of SNAP, and the Farmers to Family Food Box Program offer some much-needed relief, additional support is needed to increase food security numbers in the United States, specifically for children. Therefore, we offer the following policy recommendations to mitigate the increased food insecurity caused by the COVID-19 pandemic:

- Government institutions and organizations should anticipate long-term ramifications from the COVID-19 pandemic. The Great Recession taught us that without a significant upscaling of financial assistance, such as unemployment benefits and/or SNAP, it will likely take over a decade to achieve pre-recession food security rates. Delays in extensions and expansions of much-needed relief could create new spikes in food insecurity. Therefore, the USA should be proactive in providing financial resources to prevent unhealthy coping strategies such as skipping meals to save food for later (Niles et al. 2020) as lack of nutrition will, especially in children, lead to developmental delays and negative health outcomes (Cook et al. 2006; Wolf \& Morrissey 2017)

- While additional monetary assistance significantly reduced food insecurity, bureaucracy, ineligibility, lack of knowledge about available government subsidies, and limited funds despite receiving some subsidies many families are left without food. Therefore, food banks and charity organizations play a crucial role in immediate food assistance. As demand is expected to remain high and donations low for the foreseeable future, programs such as the Farmers to Family Food Box program should be extended and 
eventually gradually reduced until donations increase and demand declines. can increase contributions as their revenues are record high and strategic donations in particular in produce, dairy, meat, and fish products could reduce food waste. options. As many schools are closed or operating at reduced capacity, events are canceled, and doctor visits are limited, malnutrition in children may go unnoticed, and especially recently food-insecure parents may not be aware of the available resources. Therefore, institutions such as schools, churches, and medical staff should get assistance to check on the well-being of children and share information (in person, through telecommunication, and on their listservs) with parents about the importance of a nutritionally valuable diet as well as how and where to find additional assistance such as the nearest food bank.

- The underlying cause of food insecurity is systemic social, gender, and racial/ethnic inequality, among other forms of inequality persistent in the United States of America. Women and members of racial/ethnic minorities are more likely to work for low wages, to be looked over for raises and promotions, and struggle balancing work and childcare (Bateman \& Ross 2020). Financial hardships caused by gender and racial/ethnic inequalities are further exacerbated by the pandemic, in particular in households with children, leading to a higher risk of food insecurity (e.g., Leung et al. 2012; Huang, Potochnick \& Heflin 2018). Therefore, additional measures are necessary to reduce gender and race/ethnic inequality such as the enforcement of affirmative action and anti- 
discrimination laws, a minimum wage of $\$ 15$ an hour, paid maternity leave, and highquality childcare to empower families to be self-sufficient.

345
Implementing the above policy recommendations is critical in order to avoid a potential repeat ten-year setback in the fight against food insecurity as was witnessed during the Great Recession.

While immediate and short-term intervention can help keep families fed and afloat during this prolonged health and economic crisis, the long-term effects of the COVID-19 pandemic especially for families and their children of lower social class, female-headed households, and/or minorities should not be underestimated. This chapter has shown that these already vulnerable populations have been particularly hard hit in terms of food insecurity and unemployment, childcare, and the virus itself. The US government and charity organizations have a challenging task ahead to ensure healthy development of food insecure families and reduce the ever-growing social inequality gap. Our work has examined food insecurity during two economic crises in the USA, with the intention to highlight the issue and propose useful mitigation strategies learned from the past.

\section{REFERENCES}

Aday, S., \& Aday, M. S. 2020. "Impact of COVID-19 on the food supply chain." Food Quality and Safety, 4(4): 167-180.

Akkermans, J., Richardson, J., \& Kraimer, M. 2020. "The Covid-19 crisis as a career shock: Implications for careers and vocational behavior." Journal of Vocational Behavior.

Baker, M., Peckham, T., \& Seixas, N. 2020. "Estimating the burden of United States workers exposed to infection or disease: a key factor in containing risk of COVID-19 infection." PloS one, 15 (4): 1-8.

Bartfeld, J, \& Ahn, H. 2011. "The School Breakfast Program strengthens household food security among low-income households with elementary school children." The Journal of Nutrition, 141 (3): 470-475. 
Bateman, N., \& Ross, M. 2020. "Why has COVID-19 been especially harmful for working women?" Bookings, October 2020. Accessed February 2, 2021. https://www.brookings.edu/essay/why-has-covid-19-been-especially-harmful-for-workingwomen/

Blau, F., \& Kahn, L. 2017. “The gender wage gap: Extent, trends, and explanations." Journal of Economic Literature, 55 (3): 789-865.

Bleich, S., Moran, A., Vercammen, K., Frelier, J., Dunn, C., Zhong, A., \& Fleischhacker, S. 2020. "Strengthening the public health impacts of the Supplemental Nutrition Assistance Program through policy". Annual Review of Public Health, 41, 453-480.

Blinder, A., \& Zandi, M. 2010. "How the Great Recession Was Brought to an End." http://www. economy.com/mark-zandi/documents/End-of-Great-Recession.pdf.

Broad Leib, E., Ardura, A., Beckmann, J., \& King, W. 2021. An Evaluation of the Farmers to Families Food Box Program. Center for Health Law and Policy Innovation at Harvard Law School. Acessed February 2, 2021. https://www.chlpi.org/wp-content/uploads/2013/12/F2F-Food-BoxReport-Online-Final1.pdf

Boone, C., Dube, A., Goodman, L., \& Kaplan, E. 2016. "Unemployment insurance generosity and aggregate employment" No. 10439 (December): IZA Discussion Papers

Boteach. 2012. "What you need to know about the 2011 poverty data." Center for American Progress. Accessed February 4, 2021.

https://www.americanprogress.org/issues/poverty/news/2012/09/12/37674/5-things-youneed-to-know-about-the-2011-poverty-data/

Bureau of Labor Statistics. 2020. Consumer Price Index (PCI) Databases. Accessed February 5, 2021 https://www.bls.gov/cpi/data.htm

Center for Disease Control and Prevention. 2020. "United States COVID-19 Cases and Deaths by State." Accessed February 2, 2021. https://covid.cdc.gov/covid-datatracker/\#cases casesper100klast7days

Center on Budget and Policy Priorities. 2013. "November 1 SNAP cuts will affect millions of children, seniors, and people with disabilities." Accessed February 2, 2021. https://www.cbpp.org/research/november-1-snap-cuts-will-affect-millions-of-children-seniorsand-people-with-disabilities

Center on Budget and Policy Priorities. 2020. "States Are Using Much-Needed Temporary Flexibility in SNAP to Respond to COVID-19 Challenges." Accessed February 2, 2021. https://www.cbpp.org/research/food-assistance/states-are-using-much-needed-temporaryflexibility-in-snap-to-respond-to

Christiano, L., Eichenbaum, M., \& Trabandt, M. 2015. "Understanding the great recession.” American Economic Journal: Macroeconomics, 7(1), 110-67. 
Coleman-Jensen, A., Rabbitt, M., Gregory, C., \& Singh, A. 2017. "Household Food Security in the United States in 2016, ERR-237, U.S." Department of Agriculture, Economic Research Service. Accessed February 4, 2021. https://www.ers.usda.gov/webdocs/publications/84973/err237.pdf.

Congressional Research Service. 2020. "Comparing the Congressional Response to the Great Recession and the COVID-19-Related Recession: Unemployment Insurance (UI) Provisions." Accessed February 2, 2021. https://fas.org/sgp/crs/misc/R46472.pdf

Cook, J.T., Frank, D.A., Levenson, S.M., Neault, N.B., Heeren, T.C., Black, M.M., Berkowitz, C., Casey, P.H., Meyers, A.F., Cutts, D.B. and Chilton, M., 2006. "Child food insecurity increases risks posed by household food insecurity to young children's health." The Journal of nutrition, 136 (4): 1073-1076.

Department of Labor. 2020. "Families First Coronavirus Response Act: Employee Paid Leave Rights." Accessed February 2, 2021. https://www.dol.gov/agencies/whd/pandemic/ffcraemployee-paid-leave

Department of Labor. 2020. "Unemployment Insurance Relief During COVID-19 Outbreak." Accessed February 2, 2021. https://www.dol.gov/coronavirus/unemploymentinsurance\#: : :text=The\%20new\%20law\%20creates\%20the,)\%2C\%20PEUC\%2C\%20PUA\%2C\%20E xtended

Edmondson, C. 2020. "5 Key Things in the \$2 Trillion Coronavirus Stimulus Package." New York Times. Accessed February 2, 2021. https://www.nytimes.com/2020/03/25/us/politics/whats-incoronavirus-stimulus-bill.html

Elgar, F., Pickett, W., Pförtner, T., Gariépy, G., Gordon, D., Georgiades, K., Davison, C., Hammamia, N., MacNeilg, A., Azevedo Da Silva, M., \& R.Melgar-Quiñonezh, H. 2021. "Relative food insecurity, mental health and wellbeing in 160 countries." Social Science \& Medicine. Online First.

Feeding America. 2014. "Hunger in America 2014." Accessed February 3, 2021. http://www.feedingamerica.org/hunger-in-america/our-research/hunger-in-america/.

Feeding America. 2020. "The Impact of the Coronavirus on Food Insecurity in 2020." Accessed February 3, 2021. https://www.feedingamerica.org/sites/default/files/202010/Brief Local\%20Impact 10.2020 0.pdf

\section{Feeding America. 2021. "How your Donations Help Families Facing Hunger during the} Pandemic" Accessed April 7, 2021. https://www.feedingamerica.org/takeaction/coronavirus/emergency-grants

Fisher, J., Languilaire, J. C., Lawthom, R., Nieuwenhuis, R., Petts, R. J., Runswick-Cole, K., \& Yerkes, M. A. 2020. "Community, work, and family in times of COVID-19." Community, Work \& Family, 23 (3): 247-252.

Fleischhacker, S. 2020. "Strengthening the public health impacts of the Supplemental Nutrition Assistance Program through policy." Annual review of public health, 41, 453-480. 
442 Garbe, L., Rau, R., \& Toppe, T. 2020. "Influence of Perceived Threat of Covid-19 and HEXACO

443 Personality Traits on Toilet Paper Stockpiling." PLoS One, 15 (6): 1-12.

444 Goger, A., Hadden Low, T., \& George, C. 2020. “Unemployment insurance is failing workers during COVID-19. Here's how to strengthen it." Accessed February 3, 2021.

https://www.brookings.edu/research/unemployment-insurance-is-failing-workers-durig-covid-

447 19-heres-how-to-strengthen-it/

448 Grusky, D. B., Western, B., \& Wimer, C. (Eds.). 2011. “The Great Recession.” Russell Sage 449 Foundation.

450 Gundersen, C., E. Waxman, E. Engelhard, T. Del Vecchio, \& A. Satoh. 2012. "Map the Meal Gap 451 2012: A report on county and congressional district food insecurity and county food cost in the 452 United States in 2010." Feeding America. Accessed February 3, 2021.

453 https://www.feedingamerica.org/research/map-the-meal-gap/how-we-got-the-map-data

454 Gundersen, C., \& Ziliak, J. 2018. "Food insecurity research in the United States: Where we have 455 been and where we need to go." Applied Economic Perspectives and Policy, 40 (1): 119-135.

456 Gundersen, C., M. Hake, A. Dewey, E. Engelhard. 2020. "The impact of the Coronavirus on food 457 insecurity in 2020." Feeding America. Accessed February 3,

458 2021.research@feedingamerica.org.

459 Gundersen, C., Hake, M., Dewey, A., \& Engelhard, E. 2020. “Food insecurity during COVID-19." 460 Applied economic perspectives and policy. Online First.

461 Haar, Ryan. 2021. "Students: Don't Miss Your Last Opportunity to Receive Unemployment 462 Benefits." Accessed February 3, 2021. https://time.com/nextadvisor/in-the-news/last-

463 opportunity-unemployment-benefits/

464 Hagedorn, M., Karahan, F., Manovskii, I., \& Mitman, K. 2013. "Unemployment benefits and 465 unemployment in the great recession: the role of macro effects." National Bureau of Economic 466 Research. Accessed February 2,

467 2021.https://www.nber.org/papers/w19499\#: :text=Benefits\%20and\%20Unemployment\%E2\% 468 80\%A6-

469 Unemployment\%20Benefits\%20and\%20Unemployment\%20in\%20the\%20Great,The\%20Role\% 470 20of\%20Macro\%20Effects\&text=Equilibrium\%20labor\%20market\%20theory\%20suggests,job\%2 471 Ocreation\%20decisions\%20by\%20employers.

472 Heflin, C., \& Price, A. 2018. "Food pantry assistance and the great recession." Journal of Hunger 473 \& Environmental Nutrition. 14 (1-2): 225-239.

474 Huang, Y., Potochnick, S., \& Heflin, C. M. 2018. "Household food insecurity and early childhood 475 health and cognitive development among children of immigrants." Journal of Family Issues, 39 476 (6): 1465-1497.

477 Kochhar, Rakesh. 2020. "Unemployment rose higher in three months of COVID-19 than it did in 478 two years of the Great Recession." Pew Research Center. Accessed February 3, 2021. 
479 https://www.pewresearch.org/fact-tank/2020/06/11/unemployment-rose-higher-in-three-

480 months-of-covid-19-than-it-did-in-two-years-of-the-great-recession/

481 Kovalski, M. A., \& Sheiner, L. 2020. "How does unemployment insurance work? And how is it 482 changing during the coronavirus pandemic?" Brookings Institution. Accessed February 2, 2021.

483 https://www.brookings.edu/blog/up-front/2020/07/20/how-does-unemployment-insurance-

484 work-and-how-is-it-changing-during-the-coronavirus-

485 pandemic/\#: :text=The\%20CARES\%20Act\%20extended\%20the, week\%20through\%20July\%2031

486 st.\&text=One\%20out\%20of\%20five\%20eligible,large\%20as\%20their\%20lost\%20earnings.

$487 \mathrm{Ku}, \mathrm{L} .$, \& Brantley, E. 2020. "Widening social and health inequalities during the COVID-19

488 pandemic." JAMA Health Forum. 1 (6): e200721-e200721.

489 Lee, S., Hanbazaza,M., Ball, G., Farmer, A., Maximova, k., \& Willows. 2018."Food insecurity 490 among postsecondary students in developed countries." British Food Journal, 120 (11): $2660-$ 4912680.

492 Leddy, A., Weiser, S. Palar, K., \& Seligman, H. 2020. "A conceptual model for understanding the 493 rapid COVID-19-related increase in food insecurity and its impact on health and healthcare."

494 The American Journal of Clinical Nutrition, 112 (5): 1162-1169.

495 Leung, Cindy W., David R. Williams, and Eduardo Villamor. 2012."Very low food security 496 predicts obesity predominantly in California Hispanic men and women." Public health nutrition $497 \quad 15$ (12): 2228-2236.

498 Liu, W., Kolari, J., Tippens, T., \& Fraser, D. 2013. “Did capital infusions enhance bank recovery 499 from the great recession?" Journal of Banking \& Finance, 37(12), 5048-5061.

500 Long, H. 2020. "The controversial $\$ 600$ unemployment aid debate, explained." The Washington 501 Post. Accessed February 3, 2021. https://www.washingtonpost.com/business/2020/08/06/600502 dollar-unemployment-benefit/

503 Long, H., \& Bhattarai, A. 2020. "As layoffs skyrocket, the holes in America's safety net are 504 becoming apparent." The Washington Post. Accessed February 3, 2021.

505 https://www.washingtonpost.com/business/2020/03/19/unemployment-insurance-today506 coronavirus/

507 Lu, Y., Walker, R., Richard, P., \& Younis, M. 2020. "Inequalities in poverty and income between 508 single mothers and fathers." International Journal of Environmental Research and Public Health $50917(1) 135-150$.

510 Mazili, S. 2020. How producers keep the egg supply chain going amid COVID-19. Accessed 511 February 4, 2021. https://ew-nutrition.com/how-producers-keep-the-egg-supply-chain-going512 amid-covid-19/.

513 Mead, D., Ransom, K., Reed, S. B., \& Sager, S. 2020. The impact of the COVID-19 pandemic on 514 food price indexes and data collection. Monthly Labor Review 143 (1): 1-8. 
Myers, A., \& Painter, M. 2017. "Food insecurity in the United States of America: an examination of race/ethnicity and nativity." Food Security, 9(6), 1419-1432.

Morrissey, T. 2020. Addressing the need for affordable, high-quality early childhood care and education for all in the United States. Washington Center for Equitable Growth. Accessed February 2, 2021. https://equitablegrowth.org/addressing-the-need-for-affordable-highquality-early-childhood-care-and-education-for-all-in-the-united-states/

Mussell, A., Bilyea, T., \& Hedley, D. 2020. "Agri-food supply chains and Covid-19: Balancing resilience and vulnerability." Agri-Food Economic Systems. Accessed February 4, 2021. http://www.agrifoodecon.ca/uploads/userfiles/files/agrifood\%20supply\%20chains\%20and\%20covid-19\%20mar\%2022-20(1).pdf

Maria, N., Zaid, A., Catrin, S., Ahmed, K., Ahmed, A.J., Christos, I., Maliha, A. and Riaz, A., 2020. The socio-economic implications of the coronavirus pandemic (COVID-19): A review. International Journal of Surgery 78 :185-193.

National Employment Law Project. 2012. "Phase-Out of Federal Unemployment Insurance." Accessed February 4, 2021. https://www.nelp.org/wpcontent/uploads/2015/03/FactSheet_UI_Phase-Out.pdf

Niles, M. Bertmann, F., Belarmino, E. H., Wentworth, T., Biehl, E., \& Neff, R. 2020. "The early food insecurity impacts of COVID-19." Nutrients, 12(7): 1-19.

Nord, M., \& Prell, M. 2011. "Food Security of SNAP Recipients Improved Following the 2009 Stimulus Package." United States Department of Agriculture. Accessed February 2, 2021. https://www.ers.usda.gov/amber-waves/2011/june/food-security-of-snap/

Nova, A., \& Reinicke, C. 2020. "New stimulus package makes it easier to qualify for food stamps. Here's what you need to know." CNCN. Accessed February 2, 2021 https://www.cnbc.com/2020/12/30/stimulus-bill-makes-food-stamps-more-generouswhat-you-need-to-know.html

Pak, A., Adegboye, O. Adekunle, A., Rahman, K., McBryde, S., \& Eisen, P. 2020. "Economic consequences of the COVID-19 outbreak: the need for epidemic preparedness." Frontiers in public health. Online First.

Perz, S., Covington, H. Espin Moscoso, J., Griffin, L., Jacobson, G., Leite, F., Mook, A., Overdevest, C., Samuels-Jones, T., \& Thomson, R. 2018. "Future directions for applications of political economy in environmental and resource sociology: Selected research priorities going forward." Environmental Sociology, 4 (4) : 470-487.

Petts, R, Carlson, D, \& Pepin, J. 2020. A Gendered Pandemic: Childcare, Homeschooling, and Parents' Employment During COVID-19. Gender, Work \& Organization. Online First. 
549 Power, K. 2020. "The COVID-19 pandemic has increased the care burden of women and 550 families." Sustainability: Science, Practice and Policy, 16(1), 67-73.

551 Raifman, J., Bor, J., \& Venkataramani, A. 2020. Unemployment insurance and food insecurity 552 among people who lost employment in the wake of COVID-19. MedRxiv. Online First.

553 Reiley, L. 2020. Stress-baking and hoarding have led to a retail egg shortage. There are eggs in 554 the pipeline, but maybe not enough. The Washington Post. Accessed February 2, 2021.

555 https://www.washingtonpost.com/business/2020/03/26/shortages-eggs-stress-baking/.

556 Redbird, B., \& Grusky, D. 2016. "Distributional effects of the great recession: Where has all the 557 sociology gone?" Annual Review of Sociology, 42, 185-215.

558 Ryan, J. 2021. COVID-19: Global Pandemic, Societal Responses, Ideological Solutions. in COVID559 19: Global Pandemic, Societal Responses, Ideological Solutions, Edited by J. Ryan, 1-8. London: 560 Routledge

561 Terrell, K. 2020. “Congress passes $\$ 900$ billion in new stimulus relief." AARP. Accessed February 562 2, 2021. https://www.aarp.org/politics-society/advocacy/info-2020/covid-stimulus-relief.html

563 United States Department of State. 2011. "Food prices crisis of 2007-2008: Lessons learned." 564 Accessed February 2, 2021. https://reliefweb.int/report/world/foodprices-crisis-2007-2008565 lessons-learned.

566 United States Department of Agriculture. 2018." A short history of SNAP." Accessed February 2, 567 2021. https://www.fns.usda.gov/snap/short-history-snap

568 United States Department of Agriculture. 2020. "SNAP Eligibility." Accessed February 2, 2021. 569 https://www.fns.usda.gov/snap/recipient/eligibility

570 United States Department of Agriculture. 2020. "Farmers to Families Foodbox." Accessed

571 February 2, 2021. https://www.ams.usda.gov/selling-food-to-usda/farmers-to-families-food-

$572 \underline{\text { box }}$

573 United States Department of Agriculture. 2021. "COVID-19". Accessed February 9, 2021.

574 https://www.ers.usda.gov/covid-19/

575 Wandner, S. 2019. "Four decades of declining federal leadership in the federal-state 576 unemployment insurance program." Upjohn Institute Working Paper 19-314. Kalamazoo, MI:

577 W.E. Upjohn Institute for Employment Research.

578 Werner, E. 2020. "Economic relief talks between White House; Pelosi suddenly resume as 579 House Democrats make new offer. The Washington Post. Accessed February 4, 2021. Pelosi 580 suddenly resume as House Democrats make new offer 
581 Pelosi suddenly resume as House Democrats make new offer." The Washington Post. Accessed 582 February 2, 2021. https://www.washingtonpost.com/us-policy/2020/09/28/democrats-white583 house-stimulus-checks/

584 Wilde, P., \& Nord, M. 2005. "The effect of food stamps on food security: a panel data 585 approach." Review of Agricultural Economics, 27(3), 425-432.

586 Wolf, S., \& Morrissey, T. 2017. "Economic instability, food insecurity, and child health in the 587 wake of the Great Recession." Social Service Review, 91(3), 534-570.

588 Wolfson, J. \& Leung, C. 2020. Food Insecurity During COVID-19: An Acute Crisis with Long-Term 589 Health Implications. 110 (12): 1763-1765.

590 Zamarro, G., Perez-Arce, F., \& Prados, M. 2020. "Gender differences in the impact of COVID-19. 591 working paper." Switzerland: Frontiers in Public Health. Accessed February 2, 2021.

592 https://ktla.com/wp-content/uploads/sites/4/2020/06/ZamarroGenderDiffImpactCOVID-

593 19_061820-2.pdf

594 Ziliak, J. 2020. "Food hardship during the Covid-19 pandemic and Great Recession." Applied 595 Economic Perspectives and Policy. Online First.

596

597 
Table 1 Food Insecurity for Adults and Children During the Great Recession, Before and During Covid19

201

2010

2012

2014

2016

2018

2020

601

Adults $\quad 15.7 \%$

$15.2 \%$

$15.2 \%$

$13 \%$

$12.17 \%$

$15.99 \%$

602

Children

$23.4 \%$

$22.7 \%$

$22.5 \%$

$18.1 \%$

$16.88 \%$

$24.27 \%$

603 Note: This data estimates represent the state of food insecurity in the United States using the most recently

604

605 available data from the Census. As such, the data does not capture the impact of COVID-19 directly. Instead, America examined how food insecurity may increase nationally and locally based on projected changes to poverty

606 and unemployment because of the pandemic. Source: Feeding America 2010, 2012, 2014, 2016, 2018 and 2020.

607

Table 2 Food Prices Before and during Great Recession and before and Covid-19 Crises

609

610

June 2007 June 2008 \% change June 2019 June 2020 \% change

Bananas

0.512

0.633

$21.14 \%$

1.814

18.29

1.373

$14.03 \%$

1.181

$4.06 \%$

$3.45 \%$

$9.61 \%$

$33.22 \%$

$14.83 \%$

$\begin{array}{lll}0.574 & 0.588 & 2.41 \%\end{array}$

1.812

1.922

$5.89 \%$

612 Bread

1.134

2.835

3.427

3.773

$1.373 \quad 1.920$

1.280

1.474

$14.09 \%$

616

Eggs

Mean

Note: Average price data in US dollars. Bananas, tomatoes, chicken, bread, and beef per Lbs., milk per gallon, and eggs per dozen. Prices not seasonally adjusted. Source: Bureau of Labor Statistics.

620

621

622

623

624

625

626

627

628 
629 Table 3 Unemployment rate at the Peak of the Great Recession and May 2020

630

Peak Recession May 2020

631

All workers

$10.6 \%$

$13 \%$

632 Men

$12.3 \%$

$11.9 \%$

633 White

$10.6 \%$

$9.7 \%$

634 Black

$21.2 \%$

$15.8 \%$

635 Asian

$9.7 \%$

$13.3 \%$

636 Hispanic

$15 \%$

$15.5 \%$

637

638

Women

$9.4 \%$

$14.3 \%$

639 White

$7.6 \%$

$11.9 \%$

640 Black

$15.3 \%$

$17.2 \%$

641 Asian

$8.6 \%$

$16.7 \%$

642 Hispanic

$13.4 \%$

$19.5 \%$

643

644 Immigrant Status

645

U.S. Born

$10.3 \%$

$12.4 \%$

646 Foreign Born

$11.8 \%$

$15.7 \%$

647

648 Education

649 Less than High School

$17.9 \%$

$18.5 \%$

650 High School diploma

$11.9 \%$

$15.0 \%$

651 Some College

$9.0 \%$

$12.9 \%$

652 4-year bachelor's degree

$5.3 \%$

$7.2 \%$

653

654 Note: The unemployment rate reflects individuals in the labor force actively looking for work, ages and 65516 older (25 and older for the education category), non-seasonally adjusted. Estimates for the Great 656 Recession refer to the highest unemployment rate record for each group; The earliest peak was June 6572009 for Asian women and the latest July 2010 for white and Hispanic women; the earliest peak was July 6582009 for workers with at least a 4-year bachelor's degree and the latest in August 2020 for workers with 659 some college education. Source: Bureau of Labor Statistics. 
660 Table 4 National Level of Annual Summary of SNAP Participation and Costs

\begin{tabular}{lllllllll}
\cline { 2 - 8 } 661 & & 2009 & 2011 & 2013 & 2015 & 2017 & 2019 & 2020 \\
\cline { 2 - 8 } 662 & $\mathrm{~N}$ & 33,490 & 44.709 & 47,636 & 45,767 & 42,317 & 35,703 & 42,995 \\
663 & $\$$ & 50,359 & 71,810 & 76,066 & 69,645 & 63,711 & 55,621 & 36,335 \\
\hline
\end{tabular}

664 Note: Cost is presented in millions of USD. FY 2020 participation data are from April and preliminary;

665 Cost is up to July $10^{\text {th }}, 2020$; data may include disaster assistance. Data is available at

666 https://www.fns.usda.gov/pd/supplemental-nutrition-assistance-program-snap

667

668

669

670

671

672

673

674

675

676 